\title{
Mentoring and Coaching Practices for Beginner Teachers-A Need for Mentor Coaching Skills Training and Principal's Support
}

\author{
Sharmini Siva Vikaraman, Azlin Norhaini Mansor, Mohd Izham Mohd Hamzah \\ Faculty of Education, Universiti Kebangsaan Malaysia, Bangi, Malaysia \\ Email: shammyny@yahoo.com
}

How to cite this paper: Vikaraman, S. S., Mansor, A. N., \& Hamzah, M. I. M. (2017). Mentoring and Coaching Practices for Beginner Teachers-A Need for Mentor Coaching Skills Training and Principal's Support. Creative Education, 8, 156-169. http://dx.doi.org/10.4236/ce.2017.81013

Received: November 24, 2016

Accepted: January 19, 2017

Published: January 22, 2017

Copyright ( 92017 by authors and Scientific Research Publishing Inc. This work is licensed under the Creative Commons Attribution International License (CC BY 4.0).

http://creativecommons.org/licenses/by/4.0/

\begin{abstract}
Mentoring and coaching seem to have taken over many other forms of job embedded professional development programmes across the globe. Mentoring involves providing professional and personal guidance to an assigned mentee. Coaching involves providing focused career assistance to a coachee. This paper focuses on sharing current mentoring and coaching services provided particularly for beginner teachers. Beginner teachers face variety of issues and challenges in their early years of teaching. These initial experiences determine the new teachers' sustainability, teaching quality and students' performance. Effective beginner teacher mentoring and coaching includes guidance in areas of professional (career, skills and expertise) and personal (work/life balance, self-confidence, self-perception, and personal influences) development. This concept paper presents an overview of current mentoring and coaching practices for beginner teachers. The study further implies the need for providing mentors with mentor coaching skills training and principals support based on the Kansas Coaching Model underpinning the principles of Adult Learning Theory to improve current mentoring and coaching practices.
\end{abstract}

\section{Keywords}

Mentoring, Coaching, Beginner Teacher, Mentor Training, Principal Support, Kansas Coaching Model, Adult Learning Theory

\section{Introduction}

Developing and managing human resources of any organisation delivers abundance of advantages to the organisation. Building and investing on human capital aspects like skills, education, health and training are integral needs of sustaining a successful organization and its growth in the long run. Any form of investment onto the people who work in or for an organisation or institution will 
someway or other be an advantage either for the individual or the organisation they are committed to. In the case of up-skilling employees, job embedded professional development measures are becoming popular and in demand. In recent years programmes such as expert knowledge sharing, professional learning community, coaching and mentoring, in-house trainings or workshops, peer reviews, lesson studies (in schools), on job observations and action research are some measures taken within the job context.

In the educational platform, the area of human resource development places ample importance to training and development of teachers and administrators from pre-service to the in-service stage, hiring teachers, induction programmes, teacher and principal assessment and quality standards (Fullan \& Mascal, 2000). Human resource management in education dives deep into staff maintenance, staff relations, staff development procurement of staff and task performance reward (Omebe, 2014). Human resources are equally important as financial, technological and other resources considered important for the growth of any organisation. Training and development programmes for the human resources in education institution are proven essential needs to the improvement of the entire educational institution.

Under the premises of human resource management and development in education, the success of the education system relies heavily on teacher quality (Omebe, 2014). This is further taken up by the Ministry of Education continuous reforming initiatives prioritising teacher education practices and continuing professional support for teachers from the early years of teaching to retirement. Local teacher education researches are highly reaching out to share best practices and contemporary classroom instructions to teachers' professional learning and development needs in various socio-cultural contexts.

This concept paper explores the current mentoring practices provided for beginner teachers. The reviews and accounts collected, further considers the implication of an improved mentor training provision for beginner teacher mentors, in the area of classroom coaching. In order to develop an improved mentor coaching training framework, this paper has managed to:

a. Present the characteristics of mentoring and coaching for beginner teachers.

b. Describe the needs for training in coaching skills for beginner teacher mentors based on the Kansas Coaching Model (2007) by Jim Knight and Adult Learning Principles (1994) by Malcolm Knowles.

c. Describe the training areas that beginner teacher mentors need in order to improve mentoring and coaching practices.

d. Define how the school administrators and teacher leaders can support beginner teacher mentors need in order to improve mentoring and coaching practices.

This concept paper shares an overview of current beginner teacher mentoring and coaching practices to imply the need for training and support for mentors. The paper is divided to 8 sections:

a. Introduction. 
b. Beginner Teacher-Needs and Challenges.

c. Mentoring Beginner Teachers-Roles and Needs.

d. Issues and gaps in current mentoring practices.

e. Effective Mentor-Coaching-Models and Principles.

f. Why Beginner Teacher Mentors Need Coaching Skills?

g. Training Needs Analysis.

h. Implications.

These are some major concerning themes among education stakeholders in Malaysia who are taking heed in utilising mentoring and coaching as one of the most effective and practical job embedded professional development programme and support in schools nationwide. The researcher believes, this concept paper will be able to help improve current mentoring programmes as well as set a benchmark for effective mentoring practices and professional development training frameworks in the near future. In large, this paper also aims at pondering new researches in the area of strategic human capital management in education.

\section{Beginner Teacher-Needs and Challenges}

To date there are no two studies that have stated the same list of needs and challenges of a beginner teacher. Nevertheless, beginner teachers are reported to rely on the knowledge and guidance gained in the early years of teaching to determine their teaching quality for the excellence of their students.

\subsection{Needs}

Apparently some of the high-priority needs of beginner teachers are classroom management, motivating students, differentiating student learning, problems and needs, assessing student progress, interaction with colleagues and parents, receiving appropriate advice on school culture, goals and instructional resources, using effective instructional strategies or methods and emotional support (Veenman, 1984; Gordon \& Maxey, 2000; Senom \& Shahratol, 2013).

At some circumstances, even with some efforts, beginner teachers still feel isolated and hope for individualized precise support to survive the early years (Lunenburg, 2011). Literatures point out that the environment a beginner teacher is attached to shapes the quality of the teacher and teaching practices. Environment is grounded by the culture of the teaching practices and conditions of the workplace.

Mentoring beginning teachers involves providing support and assistance of an expert or experienced teacher to a new or less experienced teacher that will lead to personal growth. Support for beginner teachers is described as the materials, resources, advice and hand-holding that mentors provide (Nemser-Feiman et al., 1999). Mentors provide the space, care, personal coaching and appropriate settings for beginner teachers to gain knowledge and build strong personalities as beginner teachers embark their new career in life.

\subsection{Challenges}

Gordon and Maxey (2000) stated that, difficult work assignments, unclear goals, 
inadequate availability of resources, being in isolation, role conflict and reality shock as the 6 environmental difficulty related challenges faced by the target group upon enrolling in a school. These difficulties are further supported by other ardent beginner teacher researchers. Beginner teachers and experienced teachers are expected to deliver equal quality of work when they are often given challenging task to handle even as a novice to the school (Kurtz, 1983; Weasmer \& Woods, 2000).

A common term heard among beginner teachers known to be "reality shock" is a state of mind to deal with in their first 3 years of teaching Veenman (1984). During pre-service programmes, beginner teachers assume that real teaching is not difficult and only involves fostering students' academic performance (Weinstein, 1988; Veenman, 1984). Eventually, when they step into the real world of teaching, they are shocked by the all-round task they have to take up apart from teaching. This scenario is not informed prior to beginner their careers as full-fledged teachers.

Moir (1999) and team categorized the early stages (1st year) of teaching to 5 phases:

a. Anticipation-excited about what was learnt in pre-service, start their career, anxious.

b. Survival-faces challenges that were not anticipated in pre-service, overloaded with tasks beyond classroom teaching, shocked but need to move on.

c. Disillusionment-the most challenging phase to survive, learn to cope and adapt with multiple tasks but even more work piles up, higher expectations from administrators.

d. Rejuvenation-back into task after a semester break or schools term breaks, better understanding of their job.

e. Reflection-review what has been completed for the year and plan for the upcoming year based on the experiences and knowledge gained.

Katz (1977) in Lang (1996) describes the 4 stages of beginner teachers' development in their early years as survival, consolidation, renewal, and maturity. The survival stage of a beginner teacher lasts for the first whole year of teaching (Kagan, 1992; Katz, 1977; Reynolds, 1992 in Lang, 1996). From her interview, Lang (1996) shared that beginner teachers had to face tiredness, stress on personal and family relationships, and the lack of balance in their lives between work, domestic responsibilities, and leisure activities in the first year of survival stage. This is when they struggle to survive and some decide to leave the profession. The ones that survive eventually get eased as they progressed into their second year of service. Rajagani (2014) explains in the research on how beginner teachers get adjusted to work based on 4 aspects-self-efficacy, mentoring, person job-fit and school culture.

\section{Mentoring Beginner Teachers-Roles and Needs}

Teacher professional development plays a pivotal role in improving beginner teacher quality, student performance and school improvement as a whole (Villa$\mathrm{ni}, 2002$ ). Beginner teacher assistance programme, out of office trainings and job embedded professional development programmes e.g. mentoring, coaching and 
peer group discussions that addresses the specific daily needs of teachers and students are some popular measures. Brannan and Bleisten (2012) study on the beginner teachers' perceptions of support revealed the need for mentors' expertise in mentoring and coaching skills e.g. focused teaching and learning ideas, teaching aids, logistical knowledge by colleagues or mentors. Beginner teachers are not only new to the profession but also new to the school and the classroom.

Koki (1994) shared the guidelines by The Office of Personnel Services in the Hawaii State Department of Education (1993), to support existing mentor teacher programmes for beginner teachers. Mentors are expected to adapt good interpersonal skills, exceptional classroom pedagogical and instructional knowledge, coaching capabilities, effective communication skills and reputation, deep understanding on how adults learn and the stages of teacher development.

In recent years, mentoring has been popularly included as induction programmes for beginner teachers. Mentoring became a popular professional development measure in the 80 's was recognised as powerful and cost-effective (Huling-Austin \& Murphy, 1987). Beginner teacher mentors are depended and relied upon by the various stakeholders. Mentors are given mandates and responsibilities to support and guide beginner teachers in various ways depending on the needs of the teacher and higher authorities, funding and time (Villani, 2002). According to Villani (2002), four ways mentors can support new teachers are by providing emotional support and encouragement, information about the school's work style and culture, promoting understanding of the students and family culture; and providing cognitive coaching. Polikoff, Desimone, Porter \& Hochberg (2015), stress that the presence of the mentor in the same school provides higher quality support and mentoring services.

In a study conducted by Frazier (2006), it was reported that beginner teachers found mentoring and coaching to be beneficial in their early years of teaching, provided with adequate support, motivation, positive discussions, constant guidance and well-matched mentor. Mentors claimed mentoring beginner teachers would be effective when mentors had sufficient time, administrative support, more meetings with mentee, interest in mentoring and provided with mentoring skills. Brooks (1999), provided evidences from a case study on mentoring practices in Iowa, USA. Mentors were given release time, incentives and half day trainings to fulfill their roles by providing knowledge, ongoing support and self-development platforms to enhance beginner teachers' skills.

\section{Issues and Gaps in Current Mentoring Practices}

The need for beginner teachers to be professionally developed in the area of classroom instruction in their early years of teaching seems to demand serious attention. The transition period for a beginner teacher from a trainee to a real classroom teacher happens to be complex and yet beginner teachers in Malaysia do not receive sufficient support (Senom \& Shahratol, 2013). According to Farrell (2006), in the language teaching platform, not much research has addressed issues and challenges faced by beginner language teachers as well.

In Malaysia, the Teacher Training Division, Ministry of Education has well- 
structured a programme for the beginner teachers. This programme includes coaching and mentoring as a form of job-embedded professional development component for guiding and supporting beginner teachers in the first 3 years of their career as a teacher. This programme demands every beginner teacher to be assigned to a mentor who also plays the role of a classroom coach (Kementerian Pelajaran Malaysia, 2015). The role of the mentor is to impart knowledge to their mentee (beginner teacher) on the school culture, school environment, education system and aims. The issue is, to date these beginner teacher mentors are not trained or provided with effective mentoring and coaching skills to play their roles as mentors. Nevertheless, mentors are being blamed for not fulfilling their roles as mentors.

To date there are no researches done to investigate or assess the present mentoring and coaching practices for beginner teachers in Malaysian Secondary Schools. There has not been any extensive study conducted on the efficacy of current mentoring and coaching practices for beginner teachers to improve and sustain such initiatives. Although researches and reports claim that mentoring and coaching can provide continuous guidance and support for beginner teachers but this area still lacks investigation on its efficacy and practices. Therefore, this study applauds for investigation on current on-going mentoring and coaching given by mentors to provide meaningful support to beginner teachers through effective mentoring and coaching practices.

In Malaysia, existing professional development programmes are claimed to be lacking in follow-up support programmes, not continuous, one-shot programmes and does not promote collaboration (Senom \& Shahratol, 2013). This is contrary to alternative job embedded professional development programmes being used in countries such as U.K and U.S. Among all methods, classroom coaching has become popular over time simply because of its potential to reinforce learning following through repeated exposure to ideas and one-to-one guidance. Knight (2000) strongly suggest classroom coaching which includes one-to-one, listening, demonstrating empathy, engaging in dialogue, and communicating honestly are all a part of successful professional development.

Beginner teachers succeed when catered with professional development geared specifically toward the needs of beginner teachers; peer coaching or mentoring; easing up on the assignment of extra-class duties during the first year of service; and engaging beginner teachers in a reflective practice approach (Veenman, 1984; Gordon \& Maxey, 2000). Sadly, very little initiatives have been taken into solely monitoring the programme curriculum provided for beginner teachers in Malaysia, whereby mentors need training inputs in these areas to maximize the potential of these two partnerships.

\section{Effective Mentor-Coaching Model and Principles}

In recent years, classroom instructional coaching and mentoring have slowly been replacing traditional forms of teacher training and one-stop workshops. This is also to reduce financial constraints in organising loads of teacher training programmes, which finally goes to waste as it does not cater to what individually 
a teacher needs to improve or to be coached on. Similarly, in Malaysia, classroom instructional coaching is becoming popular replacing face-to-face workshops as a way to cut cost. According to Knight (2007), coaching in schools has sparked growing interest for many reasons, two of which are especially relevant:

a) A growing recognition that teacher quality is a critical factor in student success, and

b) An equally growing recognition that traditional forms of professional development are ineffective.

This concept paper intends to share the insights about incorporating the Kansas Coaching Model and the principles of Adult Learning theory that can provide the basis for effective beginner teacher mentoring and coaching practice. The researchers believe that the Kansas Coaching Model cycle underpinned by the principles of adult learning theory will best guide to modify current mentoring practices and boost principal support in mentoring beginner teachers to an improved level or stage.

\subsection{Kansas Coaching Model}

The Kansas Coaching Model stresses on 7 main coaching components for an effective coaching session to take place: 1) Teacher enrolment, 2) Collaborative planning, 3) Modelling the lessons, 4) Teacher-directed post-conference, 5) Observing the lesson, 6) Collaborative data exploration; and 7) Continued support. Figure 1 illustrates the process of using the Kansas Coaching Model as a coaching tool to enhance current mentoring and coaching practice. It serves as a guide to novice mentors who are inculcating coaching skills into their mentoring practices. Table 1 briefly explains each component of the Kansas Coaching Model.

These components support mentors to practice effective coaching for beginner teachers. This 7 component model provides a comprehensive and complete approach to coaching (Cornett \& Knight, 2009). It builds on a partnership approach theoretical framework in professional learning suggested by Knight (2007).

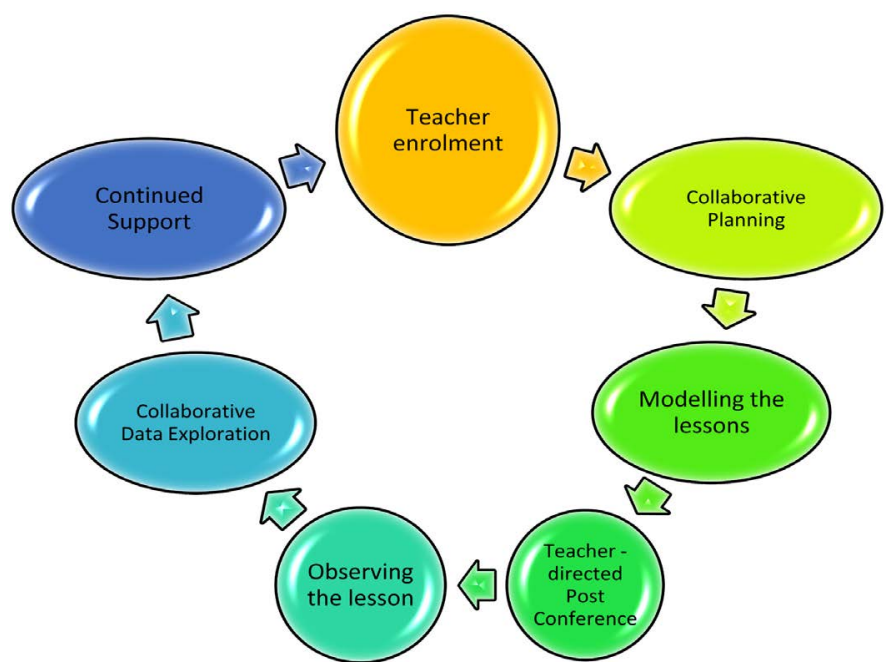

Figure 1. Kansas coaching project model by Jim Knight and Jake Cornett. 
Table 1. Components of effective instructional coaching implementation.

\begin{tabular}{|c|c|}
\hline Component & Description \\
\hline Teacher enrollment & $\begin{array}{l}\text { The coach initiates a one-on-one interview prior to engaging in professional learning activities. The interview helps build } \\
\text { common ground, develop interests and concerns, and establish a rapport between teacher and coach. }\end{array}$ \\
\hline Collaborative & $\begin{array}{l}\text { Teacher and coach collaboratively develop a practical plan for the implementation of a new teaching practice, and build a } \\
\text { rubric to help guide observation of the lesson's delivery. }\end{array}$ \\
\hline Planning & $\begin{array}{c}\text { The coach delivers the planned lesson in the teacher's classroom, while the teacher observes and records notes on the } \\
\text { observation guide. }\end{array}$ \\
\hline Modeling the lessons & Immediately following the coach's model lesson, the teacher facilitates a collaborative and constructive conversation. \\
\hline Observing the lesson & $\begin{array}{l}\text { The pair then reverses roles, with the teacher delivering the planned lesson and incorporating elements learned during the } \\
\text { previous three steps. During the lesson, the coach records observations on the rubric. }\end{array}$ \\
\hline $\begin{array}{l}\text { Collaborative data } \\
\text { exploration }\end{array}$ & $\begin{array}{l}\text { Immediately following the teacher's lesson, teacher and coach discuss the lesson, incorporating data from the coach's } \\
\text { observation rubric. }\end{array}$ \\
\hline Continued support & $\begin{array}{l}\text { The coach provides continuous support in the development of lessons and pedagogical techniques, until both parties feel } \\
\text { recognize mastery of the practice. }\end{array}$ \\
\hline
\end{tabular}

\subsection{Adult Learning Theory}

Andragogy is defined as learning strategies focused on teaching adults. Pratt (1993) in Narishkin (2008), explained andragogy as a theory that gives importance to adults learning by giving learners high autonomy and space for reflective learning to take place. Andragogy puts the learner in the center of a lesson and allows learners to construct knowledge through experiences and self-goals (Cohen, 1995). The Andragogical Process Model by Malcolm Knowles (1974) stresses that when handling adults, trainers need to be skilled in:

a. Establishing a climate conducive to learning-a learning environment based on mutual respect and trust.

b. Creating a mechanism for mutual planning-learners share responsibility for planning.

c. Diagnosing the needs for learning-learners feel a need to learn.

d. Formulating program objectives (which is content) that will satisfy these needs-goals of the learning experience are the learners goals.

e. Designing a pattern of learning experiences-learning process uses learners experiences.

f. Conducting these learning experiences with suitable techniques and materials-active learning and participation by learners.

g. Evaluating the learning outcomes and re-diagnosing learning needshave a sense of progress towards goals.

Knowles et al. (1984) stresses on self-directed learning which supports adults' way of learning or acquiring knowledge- "the most effective self-directed learners are highly skilful in getting help form peers, teachers, printed meterials, audiovisuals aids and every kind of resources". In terms of this research, andragogy allows beginner teachers and mentors to set their own time, pace resources and methods of giving and receiving mentoring services. Teachers should take higher responsibilities in their self-development and learning process to gain experience in their related field. On the other hand, programmes and any other method of support for beginner teachers should adopt the theory of adult learning for ef- 
fective transfer of knowledge and contribution of their learning. This strongly includes principals' knowledge on adult learning theories is equally critical in knowing that beginner teachers, being young adults, have equal rights as experienced teachers without any discrimination.

\section{Why Beginner Teacher Mentors Need Coaching Skills?}

Mentoring and coaching are not the same but have similar attributes. Mentoring involves helping mentees (teachers) in areas of professional (career, skills and expertise) and personal (work/life balance, self-confidence, self-perception, personal influences) by building relationship. Mentors in general are much more experienced and are able to share with their mentee (beginner teacher) about school policies, rules, school culture, protocols; teaching methods and related issues, provide personal and professional support; and guide the new teacher through reflection and professional discussions (Koki, 1994; Rajagani, 2014). On the other hand, coaching involves goal-focused learning by unleashing the true potentials of a teacher in the area of self-knowledge, behavioral change, and career development. In short, mentoring is relationship oriented and coaching is task orientated. Coaching is a subset of mentoring.

Mentoring and coaching is not a simple task that any mentor could fulfil without adequate training or input about how coaching is done. A mentor's job as a coach requires some form of proper coaching methods. Gibson (2005) stated that coaches should not try to address everything that a teacher could improve in any one coaching session; coaches need to know how to identify a specific focus for the coaching discussion that will best help the teacher to move forward in his/her understanding of effective teaching. Evertson and Smithey (2000) reported that beginner teachers working with trained mentors had higher level of teaching skills than with mentors who were not trained.

Research claims that mentors lack mentoring skills and needs upskilling to play their roles effectively (Gordon \& Maxey, 2000). Some aspects to be considered as preparation before a mentor starts mentoring officially or before the beginner teacher arrives are:

a. Knowledge about teacher induction.

b. Developing trust and rapport.

c. Classroom management and effective teaching.

d. Adult learning.

e. Adult and teacher development.

f. Observation skills.

g. Interpersonal skills.

h. Problem solving skills.

i. Specialized training.

j. Planning and time management.

It is advisable for schools to always have well trained mentors in hand. A well trained mentor can be matched with the most suitable beginner teacher candidate. A mentor, being an experienced teacher is likely to take up other support tasks or staff development programmes as well e.g. head of department, class- 
room teacher, subject panel head, event managers, student training and student affair consultants. Currently, mentors are deprived of appropriate mentoring and coaching skills training or professional development for themselves before they can even provide the coaching for beginner teachers. There are no valid evidence showing continuous support and trainings for mentors to pursue an established or critical role as a mentor.

A mentor plays two major functions in supporting teachers-career and psychological (Smith \& Ingersoll, 2004). The career functions include providing the mentee with sponsorship, exposure and visibility, coaching, protection, and challenging assignments. The psychological functions provide the mentee with role modelling, acceptance and confirmation, counselling, and friendship. Therefore coaching skills which includes modelling is essential to a mentor. Mentoring beginner teachers demands for clear directions and professional trainings in order to develop beginner teachers' quality of teaching (career) and improve their personal life (psychology). The conceptual framework suggested in this paper, will be able to serve as a benchmark or guide to principals and administrators to provide adequate support for beginner teachers and teacher leaders as professional development is critically important for school improvement.

\section{Training Needs Analysis}

Prior to embarking in this research, the researchers conducted a survey using Google Sheets to identify the beginner teacher mentor training and support needs. The survey was administered among a group of 20 English Language Teachers consisting beginners, mentors and experienced teachers. 13 responded to the survey and the findings are as below. The survey finding shares the needs of a mentor training programme and inputs.

\begin{tabular}{|c|c|c|c|c|c|}
\hline Mentor training needs & Little or no need & Some need & Moderate need & High need & Very high need \\
\hline Mentor roles, theory, principles & & & $30.8 \%$ & $61.5 \%$ & $7.7 \%$ \\
\hline Give support and encouragement & $7.7 \%$ & $7.7 \%$ & & $38.5 \%$ & $46.2 \%$ \\
\hline Interpersonal skills & & $7.7 \%$ & $23.1 \%$ & $30.8 \%$ & $38.5 \%$ \\
\hline Classroom management & & & $30.8 \%$ & $30.8 \%$ & $38.5 \%$ \\
\hline Modelling & & & $30.8 \%$ & $30.8 \%$ & $38.5 \%$ \\
\hline $21^{\text {st }}$ century strategies & & $7.7 \%$ & $15.4 \%$ & $46.2 \%$ & $30.8 \%$ \\
\hline Adult learning theory & & $15.4 \%$ & $15.4 \%$ & $53.8 \%$ & $15.4 \%$ \\
\hline Information on school & $7.7 \%$ & $15.4 \%$ & $23.1 \%$ & $23.1 \%$ & $30.8 \%$ \\
\hline Student discipline, motivation & & $15.4 \%$ & $15.4 \%$ & $23.1 \%$ & $46.2 \%$ \\
\hline Resources and materials & $7.7 \%$ & $7.7 \%$ & $15.4 \%$ & $46.2 \%$ & $23.1 \%$ \\
\hline Role model & $7.7 \%$ & $15.4 \%$ & & $46.2 \%$ & $30.8 \%$ \\
\hline Co-teaching & & $7.7 \%$ & $15.4 \%$ & $30.8 \%$ & $46.2 \%$ \\
\hline Managing time & & & $23.1 \%$ & $38.5 \%$ & $38.5 \%$ \\
\hline Student needs, learning style & & $7.7 \%$ & $15.4 \%$ & $38.5 \%$ & $38.5 \%$ \\
\hline Student progress & & $7.7 \%$ & $23.1 \%$ & $38.5 \%$ & $30.8 \%$ \\
\hline Classroom coaching & & & $30.8 \%$ & $30.8 \%$ & $38.5 \%$ \\
\hline Principal support & & $7.7 \%$ & $23.1 \%$ & $38.5 \%$ & $30.8 \%$ \\
\hline Admin support & & $7.7 \%$ & $15.4 \%$ & $30.8 \%$ & $46.2 \%$ \\
\hline
\end{tabular}


The response to the need of adequate training in mentoring and coaching skills gathered some personal views such as:

a. Mentors need to be trained to provide a comfortable working space for beginner teachers.

b. Mentors need to balance their time well as teachers and teacher leaders themselves.

c. Mentors play very important role in providing emotional support.

d. Mentors need to be trained based on contemporary needs.

e. Mentors need to be aware of their roles and tasks.

f. Mentors need to read up as mentoring is complex.

This survey also gathered some opinions on how principals and administrators can provide support to mentors.

a. To abolish current beginner teacher development programme that requires more commitment towards paper work than actual mentors' assistance.

b. Principals and panel heads to constantly monitor mentoring and coaching progress.

c. Give moral support, encouragement and sincere advice.

d. Allow mentors to attend courses.

e. Reduce mentor's workload as they play various roles.

f. Have regular meetings and observations.

\section{Implications}

\subsection{Mentor Training Programme}

"If the teacher won't do the job, you have a motivational problem. If the teacher can't do it, you have a training problem".

-Richard E. Smith (2009)

Mentoring is being practiced in Malaysia as a measure to cater to the needs of beginner teachers to improve their teaching quality and student performance. Nevertheless, beginner teachers have different opinions and plight when asked about receiving mentoring services as their professional development measure and self-development assistance. Sweeney (2011) outlined an effective and meaningful mentoring programme. Successful mentor training programmes includes very clear expectations and roles played by the mentor according to the needs of the beginner teacher supported by the administration and peers. The mentors are additionally provided with time for coaching and collaborative planning, attend special self-development mentor trainings and assistance from other mentor experts. An effective mentoring programme too includes on-going evaluation for programme improvement purposes. This paper highly recommends mentors to use the Kansas Coaching Model and the principles of Adult Learning as their guide to effective beginner teacher mentoring sessions.

\subsection{Principal Support}

Smith (2009) shares that beginner teachers take time to build good rapport with principals due to the perceptions beginner teachers have on their principals as 
authoritative. School principals have great influence on teacher professional development (Bredeson, 2000). Cherrian \& Daniel (2008) and Smith (2009) strongly presented their case on how principals can become the agent of support to beginner teachers by providing appropriate working environments, constant supervision, allocating sufficient time and resources. Supporting beginner teachers is likely to produce changes in the teachers' continuous practices, believes and progress in becoming expert teachers for both mentor and beginner teacher mentoring purpose; and playing a significant role in the overall induction programme.

\section{Conclusion}

The researchers strongly believe that, effective mentor training and adequate administrative support are important factors to sustain quality of teaching for beginner teachers and taking up responsibilities as teacher leaders e.g. mentors, who play various roles apart from being a teacher. Effective human capital management and development eventually produces quality service and performance. If education stakeholders believed that mentoring and coaching can help beginner teachers face their beginning years confidently, then it is about time to monitor and provide necessary support for both beginner teachers and mentors for a much sustained roles they will play in the school environment. Mentoring programmes should incorporate coaching skills training and principals should start playing significant roles in the area of human capital development. In the near future, to produce the best teachers, improve instructional practices and the quality of student learning experiences, research on strategic management of human capital development in the areas of-recruitment, selection, staffing, induction/mentoring, professional development, performance management/evaluation, and compensation will be beneficial for beginner teachers and teacher leaders.

\section{Acknowledgements}

We sincere acknowledge to my Supervisors Dr. Azlin Nurhaini Mansor and Assoc. Prof. Dr. MohdIzham Mohd Hamzah for their constant support, guidance and encouragement to embark and complete this concept paper. Our sincere acknowledgement to-Dr. Jayanti Sothinathan (UCSI), Dr. Sivabala Naidu (Nottingham), post-graduate academic partners Vasanthan Gurusamy (UPSI), Nitce Isa Medina Machmudi Isa (UKM) and Zubaidah Ali (UKM) for their kind contributions towards completing this paper.

\section{References}

Brannan, D., \& Bleistein, T. (2012). Novice ESOL Teachers' Perceptions of Social support Networks. TESOL Quarterly, 46, 539-541. https://doi.org/10.1002/tesq.40

Bredeson, P. V. (2000). The School Principal's Role in Teacher Professional Development, Journal of In-Service Education, 26, 385-401.

https://doi.org/10.1080/13674580000200114 
Brooks, M. (1999). Mentors Matters. In M. Scherer, A Better Beginning: Supporting and Mentoring New Teachers (pp. 53-59). Alexandria, VA: Association for Supervision and Curriculum Development.

Cherrian, F., \& Daniel, Y. (2008). Principal Leadership in New Teacher Induction: Becoming Agents of Change. International Journal of Education Policy and Leadership, 3, 1-11.

Cohen, N. (1995). Mentoring Adult Learners: A Guide for Educators and Trainers. Malabar, FL: Kreieger Publishing Company.

Cornett, J., \& Knight, J. (2009). Research on Coaching. Coaching: Approaches and Perspectives, 192-216.

Evertson, C., \& Smithey, M. (2000). Mentoring Effects on Protégés' Classroom Practice: An Experimental Field Study. Journal of Educational Research, 93, 294-304. https://doi.org/10.1080/00220670009598721

Farrell (2006). The First Year of Language Teaching: Imposing Order. System, 34, 211 221. https://doi.org/10.1016/j.system.2005.12.001

Fullan, M., \& Mascall, B. (2000). Human Resource Issues in Education. Ontario Institute for Studies in Education of the University of Toronto.

Gordon, S. P., \& Maxey, S. (2000). How to Help Beginner Teachers Succeed. Alexandria, VA: Association for Supervision and Curriculum Development.

Huling-Austin, L., \& Murphy, S. C (1987). Assessing the Impact of Teacher Induction Programs: Implications for Program Development. Paper Presented at the Annual Meeting of the American Educational Research Association, Washington DC.

Kagan, D. (1992). Professional Growth among Preservice and Beginner Teachers. Review of Educational Research, 62, 129-169. https://doi.org/10.3102/00346543062002129

Katz, L. (1977). Talks with Teachers: Reflections on Early Childhood Education. Washington DC: National Association for the Education of Young Children.

Kementerian Pelajaran Malaysia (2015). PanduanPelaksanaan Program Pembangunan Guru Baharu (PPGB) di Sekolah-sekolah di bawah Kementerian Pelajaran Malaysia.

Knight, J. (2000). Another Damn Thing We've Got to Do: Teacher Perceptions of Professional Development. Paper Presented at the Meeting of the American Educational Research Association, New Orleans, LA.

Knight, J. (2007). Instructional Coaching: A Partnership Approach to Improving Instruction. https://doi.org/10.1017/CBO9781107415324.004

Knowles, M. (1974). Human Resources Development in OD. Public Administration Review, 34, 115-123. https://doi.org/10.2307/974934

Knowles, M. et al. (1984). Andragogy in Action. Applying Modern Principles of Adult Education. San Francisco: Jossey-Bass.

Koki, S. (1994). The Role of Teacher Mentoring in Educational Reform (pp. 1-6). Education No. 808 .

Kurtz, W.H. (1983). How the Principal Can Help Beginning Teachers. NASSP Bulletin, 67, 42-45. https://doi.org/10.1177/019263658306745908

Lang, C. (1996). When Does It Get Any Easier? Beginning Teachers' Experiences during Their First Year of Teaching. Centre for Teacher Education University of Waikato.

Lunenburg, F. C. (2011). Orientation and Induction of the Beginner Teacher. National Forum of Educational Administration \& Supervision Journal, 29, 1-5.

Moir, E. (1999). The Stages of a Teacher's First Year. In S. Villani (Ed.), Mentoring Porgrams for New Teachers: Models of Induction and Support (p. 6). Thousand Oaks, CA: Corwin. 
Narishkin, A. S. (2008). A Formative Evaluation of the Beginning Teacher Assistance Program: An Andragogical Approach. Doctoral Dissertation, Saint Louis, MO: University of Missouri.

Nemser-Feiman, S., Carver, C., Schwille, S., \& Yusko, B. (1999). Beyond Support: Taking New Teachers Seriously as Learners. In M. Scherer (Ed.), A Better Beginning: Supporting and Mentoring New Teachers (pp. 3-12). Alexandria, VA: Association for Supervision and Curriculum Development.

Omebe, C. A. (2014). Human Resource Management in Education: Issues and Challenges. British Journal of Education, 2, 26-31.

Polikoff, M., Desimone, L., Porter, A., \& Hochberg, E. (2015). Mentor Policy and the Quality of Mentoring. The Elementary School Journal, 116, 76-102.

https://doi.org/10.1086/683134

Rajagani Diwyaa, V. (2014). Relationship between Mentoring, Self-Efficacy, Person Job-Fit and School Culture with Work Adjustment among New Teachers. Asian Social Science, 10, 90-98.

Reynolds, A. (1992). What Is Competent Beginning Teaching? A Review of the Literature. Review of Educational Research, 62, 1-35. https://doi.org/10.3102/00346543062001001

Senom, F., RazakZakaria, A., \& Sharatol Ahmad Shah, S. (2013). Novice Teachers' Challenges and Survival: Where Do Malaysian ESL Teachers Stand? American Journal of Educational Research, 1, 119-125. https://doi.org/10.12691/education-1-4-2

Smith, R. E. (2009). Human Resources Administration: A School-Based Perspective. New York: Eye on Education Inc.

Smith, T. M., \& Ingersoll, R. M. (2004). What Are the Effects of Induction and Mentoring on Beginning Teacher Turnover? American Educational Research Journal, 41, 681-714. https://doi.org/10.3102/00028312041003681

Sweeney, B. W. (2011). Leading the Teacher Induction and Mentoring Programme. Arlington Heights, IL: SkyLight Training and Publishing Inc.

Veenman, S. (1984). Perceived Problems of Beginner Teachers. Review of educational Research, 54, 143-178. https://doi.org/10.3102/00346543054002143

Villani, S. (2002). Mentoring Programs for New Teachers. Thousands Oaks, CA: Corwin Press Inc.

Weasmer, J. \& Woods, A. M. (2000). Preventing Baptism by Fire: Fostering Growth in New Teachers. Clearing House, 73, 171-173. https://doi.org/10.1080/00098650009600941

Weinstein, C. S. (1988). Pre-Service Teachers' Expectations about the First Year of Teaching. Teaching and Teacher Education, 4, 31-40. https://doi.org/10.1016/0742-051X(88)90022-4 
Submit or recommend next manuscript to SCIRP and we will provide best service for you:

Accepting pre-submission inquiries through Email, Facebook, LinkedIn, Twitter, etc. A wide selection of journals (inclusive of 9 subjects, more than 200 journals)

Providing 24-hour high-quality service

User-friendly online submission system

Fair and swift peer-review system

Efficient typesetting and proofreading procedure

Display of the result of downloads and visits, as well as the number of cited articles Maximum dissemination of your research work

Submit your manuscript at: http://papersubmission.scirp.org/

Or contact ce@scirp.org 